\title{
What female pop-folk celebrity in south-east Europe tells postsocialist feminist media studies about global formations of race
}

\section{Catherine Baker}

University of Hull

This is an Accepted Manuscript of an article published by Taylor \& Francis in Feminist Media Studies on 03 Apr 2019, available online: https://www.tandfonline.com/doi/

full/10.1080/14680777.2019.1599035.

\begin{abstract}
Feminist media studies of postsocialism are well practised at explaining how ideologies of gender and nation reinforce each other amid neoliberal capitalism on Europe's semi-periphery. They extend this, by critiquing media marginalization of Roma, into addressing regional formations of race. Yet they rarely go on to contextualize the region's place within "race" as a global structure of feeling, or how transnational processes of "race in translation" operate in postsocialism - as necessary as this would be to fulfil ever-more-frequent calls to combine postsocialist and postcolonial analytical lenses. Vestiges of racial exceptionalism thus still often characterize postsocialist studies despite Anikó Imre's intervention against them more than a decade ago. This paper traces how south-east European pop-folk music's politics of representation, "modernity" and "Balkanness" interact with aesthetics of ethnic/racial ambiguity in Western female celebrity to translate globalized, racialized tropes of exoticism into postsocialist national media cultures. By explaining how popfolk female celebrity translates the transnational racialized aesthetics of so-called "ethnic simultaneity" into postsocialist glamour, the paper puts Imre's intervention against racial exceptionalism into practice, expanding postsocialist feminist media studies' conceptual tools for understanding the regional politics of ethnicity into engagement with the global politics of race.
\end{abstract}

Keywords: celebrity; pop-folk music; postsocialism; race; south-east Europe

Word count: 6,254 
For several months in 2009-10, Serbian tabloid readers noticing a female celebrity wearing tight black dresses, high shoulder-pads and a honey-blonde undercut, holding up a teasing, tattooed finger, might not have immediately known if they were seeing the Serbian singer Seka Aleksić or Rihanna, whose then-similar image was being transmitted around the world. Aleksić, a "pop-folk" star since 2004, exemplifies post-millennial female celebrity in this contentious, sexualized musical genre, which post-Yugoslav/postsocialist feminists have frequently criticized since a form of it called "turbo-folk" emerged in Slobodan Milošević's Serbia in 1994-5. Other south-east European (SEE) countries have equivalents. The globalized aesthetics of glamour, especially (since the 1990s) styles of fashion, behaviour and dance associated with hip-hop/R\&B, ${ }^{1}$ have long been resources adopted by female pop-folk stars for constructing their celebrity. Postsocialist feminist media studies confidently situates pop-folk celebrity at the interstices of gender, ethnonationalism, globalization and neoliberal capitalism. Until now, however, it has rarely acknowledged that pop-folk celebrity also involves translations of style within racialized, as well as neoliberal, transnational economies of desire.

Black, postcolonial and decolonial feminist critique, however, would probably question translations of US-centred R\&B style into SEE pop-folk glamour much more readily. It might ask how US-centred R\&B's racialized representations are re-racialized when SEE producers of "celebrity" adapt them; what cultural imaginaries of blackness and "race" circulate in SEE political economies of exoticism, desire and modernity; perhaps even whether SEE adoptions of black women's style would constitute appropriations across racialized boundaries as they might if a US-based white woman made them. Postsocialist media studies still rarely explores such questions, despite Anikó Imre's important calls for a

\footnotetext{
1 "Contemporary R\&B," not older "rhythm and blues."
} 
"postcolonial media studies in postsocialist Europe" (Imre 2014), which would surely have to. In 2005, Imre was already arguing white supremacy was "rooted much deeper" in east European national identities than local or Western scholars were acknowledging, and that postsocialist "politics and aesthetics" of whiteness had wrongly "remained beyond analysis" (Imre 2005: 80). They largely still remain beyond analysis, even though calls for scholars to organically connect the effects of state socialism's transnational collapse with the legacies of colonialism and decolonization (Chari and Verdery 2009) should have provided the platform for such work.

The downplaying of race in postsocialist feminist media studies is more glaring now many more white feminists have encountered intersectionality theory via women of colour's (often unremunerated (Dzodan 2016)) digital activism. While white European feminists' adoptions of intersectionality have sometimes been criticized for erasing racist oppression (Bilge 2013), some postsocialist feminist/queer scholars directly credit African-American women's theorization of intersectionality for helping them expose local gendered and sexualized racisms which typical postsocialist studies paradigms of gender/nation might miss (see Bilić and Kajinić 2016). Some might object that postsocialist racial formations are too distinct from US or other Western ones for intersectional perspectives to apply to SEE (see Todorova 2009: 195). Recognising that SEE cultural theory and critical race theory are both concerned with the projection of judgements about "modernity"/"primitivism" onto different territorial spaces and cultures, however, overcomes that objection: the dynamics of racialization revealed by critical race theory are, this paper shows, already at work in SEE.

This paper thus illustrates how postsocialist feminist media studies can incorporate the politics of race and whiteness into theorizing gender, capitalism and ethnonationalism. Nadia Kaneva (2015: 5) has already argued that the "historical and ideological legacies" which shape "constructions of post-socialist femininities" include the global legacies of 
colonialism and slavery, especially the worldwide permeation of "race." A transnational feminism that recognises "the cultural and economic inequities of globalization" (Shome 2006: 255) in SEE must therefore address reverberations of Western racializations of gender, sexuality and the body, including one of their most prominent postsocialist expressions: popfolk female celebrity. By explaining how pop-folk female celebrity translates the transnational racialized aesthetics of so-called "ethnic simultaneity" into postsocialist glamour, the paper puts Imre's intervention against racial exceptionalism into practice, expanding postsocialist feminist media studies' conceptual tools for understanding the regional politics of ethnicity into engagement with the global politics of race.

Discourses of modernity, tradition and primitivism in south-east European national identities

Almost all studies of postsocialism and pop-folk deal with the symbolic politics of "modernity" and "tradition"/"primitivism" in SEE national identities. Across the region, popfolk's national variants share vocal practices, rhythms, instrumental ornamentations, imagery and dance that reference traditional music in deliberately "modern," not "authentic," ways (Buchanan (ed.) 2007; Samson 2013). These include replacing accordion ornamentations with synthesizers, and using traditional folk-song tropes/vocabulary to dramatize contemporary social change. ${ }^{2}$ Since most SEE national histories involve struggling for

\footnotetext{
${ }^{2}$ Pop-folk differs from more deliberately reconstructive neo-traditional music. Marketed as "etno"/"world music," this targets audiences identifying themselves as "cosmopolitan," “discerning” and "cultured" in class and taste terms (Čolović 2006).
} 
independence against the Ottoman Empire, musical signifiers of Ottoman cultural heritage (predating 20th-century national borders) carry powerful symbolic associations of "the Balkans" and "the East." Such sonic and embodied signifiers mark pop-folk as "oriental." Throughout SEE, indeed, "Balkanness"/“"Easternness” marks symbolic Self-Other boundaries. These ascribe "Europeanness"/“modernity" to collective national selves while placing certain national Others (to the south/east) across stigmatized frontiers of cultural difference. The "Balkans," frequently mediated through exoticized imaginations of Romani culture, still represent an exotic, sensual, guilty pleasure (van de Port 1998). Once hidden from European sight (Herzfeld 2005), the Balkans in today's cultural marketplace can be knowingly repackaged for sale to a West which thirsts for not-quite-European exoticism (Buchanan 1997). These constructions interact with two-and-a-half centuries of Western/European “othering” of the Balkans, and with SEE's continued economic marginality as a European “semiperiphery” (Blagojević 2009). There, early postsocialist hopes for prosperity were dashed by clientelistic privatizations compounded (for exYugoslavs) by war. In fact, similar identity discourses in Greece and Turkey (see Stokes 1992; Buchanan (ed.) 2007) suggest these dynamics even predate state socialism, though the Cold War exacerbated them.

Postsocialist cultural theorists have explained these discourses via postcolonial thought, especially Said's Orientalism. The break-up of Yugoslavia brought them into view when Slovenian and Croatian nationalists emphasized their own modern, central-European, Habsburg heritage and framed south-eastern republics as permanently confined within traditionalistic and backward mentalities acquired under Ottoman rule. Milica Bakić-Hayden (1995) termed this "nesting orientalisms" - since Slovenes' "Balkans" started in Croatia, yet Croatian intellectuals detached themselves from "the Balkans" too. Maria Todorova (2009) adapted orientalism into "balkanism" to name Western travellers' and writers' exoticization 
of "the Balkans" as a wild, dangerous periphery to define civilized Europe against. Todorova (2009: 194-5) did not consider the Balkans as Ottoman colonies, and arguably "forecloses 'race”” from studies of SEE (Bjelić 2017: 224). She and Bakić-Hayden, however, inspired many critical commentaries on SEE media to use postcolonial thought in explaining the globalized pressures promoting self-exoticization in postsocialist cultural economies (see Volčič 2013).

"Balkanism" also helps explain why pop-folk provokes cultural anxieties. Pop-folk emerged under late state socialism (see Rasmussen 2002; Buchanan 2006) and ever since has connoted a stigmatized peripheral urban working class who had moved from villages to newly-industrialising city districts. Self-identified city-dwellers made symbolic value judgements based on taste and consumption to distance themselves from this new working class, whom they perceived as importing "peasant" mentalities (Dragićević-Šešić 1994; Gotthardi Pavlovsky 2014). Pop-folk’s sonic-linguistic-visual-embodied “Balkan” signifiers both denote the Ottoman past and reveal historico-cultural similarities across ethnonational boundaries, destabilizing postsocialist national identity-making projects.

The cultural anxieties of balkanism are inseparable from the racialization of the Roma (Haliliuc 2015), SEE's only visibly-different and transnationally structurally-marginalized minority (McGarry 2017; Rucker-Chang, forthcoming). In fact, ethnomusicological research about Romani musicians (straddling live and mediated performance) is where SEE media studies come closest to the approach of Imre (2005), who studies Roma representation herself. Romani professional musicians are historically important in SEE folk traditions (including those adapted in pop-folk), unsettling the tradition-bearing nation's supposed monoethnicity and whiteness. They negotiate simultaneous sentiments of "appreciation yet hostility" from majority communities (Beissinger 2001: 24), charged with giving non-Roma licence for wild behaviour in transgressive spaces (van de Port 1998) while national folk 
traditions position them as "the Others from within" (Pettan 2001). Their role as "agents in the making of cultural difference" (Beissinger 2001: 26) sees them make "strategic performances" (Marković 2015) of authenticity, primitivity, hybridity. cosmopolitanism and difference in local, national and "world" musical economies. Yet they are marginalized at the highest tiers of business and celebrity (Silverman 2012: 185), and their contributions to national musical traditions are often erased in presentations of the nation that emphasise white, ethnic-majority identity for an international gaze, such as some performances in Eurovision (Szeman 2013). While Romani presence in folk musical tradition might disturb nationalist ideological premises, structural racism contains the potential disruption.

Pop-folk thus seems to unsettle nationalism in some ways and reinforce it in others. In practice, many feminist critics nevertheless argue pop-folk upheld postsocialist nationalism through a patriarchal gender order. Stereotypically, pop-folk depicted "erotically aggressive," silicone-enhanced women surrendering to tough, often criminal, men while organized criminals were leveraging privatization and economic sanctions to become a new postsocialist social elite (Kronja 2004: 109; Ibroscheva 2013). This occurred amid a broader postsocialist "retraditionalization" (Verdery 1994: 250) of gender in public culture, above all in the war-affected Yugoslav successor states (Žarkov 2007). These dynamics permeated media including advertising, women's magazines, cinema and pop-folk.

The political economy of postsocialist pop-folk female celebrity

Feminist approaches to pop-folk and postsocialist media combine critiques of ethnonationalism with wider feminist perspectives on aesthetic, embodied and affective labour in entertainment. During Milošević's rule, for instance, the mass culture critique of Serbian turbo-folk considered its kitsch, "pornographic" (Kronja 2004: 105) aesthetics to 
have imposed a hegemonic patriarchal nationalism on media by driving out any political/cultural ideological alternatives (Gordy 1999; Papić 2002). Female pop-folk celebrities embodied the emblematic postsocialist "sponzoruša" ("sponsored woman"), strategically using sexuality to attract a wealthy man to fund her material desires. Turbo-folk outlasted Milošević within Serbia and enjoyed demonstrable underground popularity even in Croatia and Bosnia, but its representations of women still troubled post-Milošević feminists. ${ }^{3}$ Marija Grujić, for instance, argued turbo-folk supported ideological pressure on women to take heteronormative places within their ethnonational community by making these representations pleasurable and everyday. Although turbo-folk sometimes conveyed minority (Romani or queer) identities by adopting global R\&B/hip-hop aesthetics, she considered this just appropriated minority identities into heteronormative and ethnonationalist ideologies rather than reframing any dominant representations (Grujić 2009: 31).

Olga Dimitrijević, meanwhile, emphasized that critical controversies around whether turbo-folk was solely an ideological tool or could also subvert ethnonationalism were struggles over meanings of the female body. Both late Yugoslav and post-Yugoslav pop-folk had dramatized intimate hardships of rapid urbanization and, later, postsocialist "transition." Achieving celebrity involved transformations in style, body-image and consumption that distanced stars from emerging singers' more "natural" personas. This reflected their rise through postsocialist class-structures, and offered women disadvantaged by transition some escapist identification, but did not disturb the postsocialist social order (Dimitrijević 2008: 45-6).

In the 2010s, feminist pop-folk research often suggested it documented everyday experiences of transition, through fantasies of female entrepreneurship permitting young (and

\footnotetext{
${ }^{3}$ Fewer studies cover post-Yugoslav pop-folk masculinities, but see Dumančić and Krolo 2017.
} 
older) women to make sense of their own aspirations and situation. Young Slovene/Croat women, for instance, might "paradoxically” identify with the Serbian star Ceca Ražnatović, who (in)famously married a paramilitary commander in 1995. Zala Volčič and Karmen Erjavec (2010: 103-4) resolved this paradox by suggesting Ceca's star image by the mid2000s represented "a depoliticized pop culture commodity," promising "a new type of personal empowerment" to young women without undermining the neoliberal postsocialist/post-conflict economic structures that disempowered them. By this time, postsocialist hopes of a "return to Europe" were dissipating in SEE, where the public widely considered that European political/financial institutions had consigned SEE to a perpetual semi-periphery. A "reparative reading" of the derided sponzoruša thus saw her as "a motif of feminine libidinal entrepreneurship" within SEE's “transitional, post-socialist, neoliberal capitalist economies:" her "promise of upward mobility," when postsocialist life chances had deteriorated not improved, gave pop-folk its “affective appeal” (Jelača 2015: 38-9).

Similar conjunctions exist across SEE. Pop-folk seems to epitomize the postsocialist hypersexualization of media in Romania as much as Serbia (Haliliuc 2015: 299). Likewise, Bulgarian, Bosnian and Serbian pop-folk all interprets and commercializes the pan-regional Ottoman past for fellow "Balkan" listeners through gendered "orientalized musical eroticism" via čoček dance (Buchanan 2007: 248). An emerging argument that contemporary pop-folk creates "a Balkan identification [...] that implicitly includes but also transcends the nationstate" (Archer 2012: 199), indeed, even decentres nationalism in favour of transnationalism as a framework for understanding pop-folk. Pop-folk studies engage deeply with ethnicity, nationalism and social inequality, even racialized antiziganism, and they recognise the adoption of hip-hop/R\&B aesthetics as a kind of "glocalization" - but very rarely situate it within global formations of race. Outside important research on Romani hip-hop, 
postsocialist media studies thus rarely address US-centred popular music's racial politics, and how their stylistic codes are adapted in SEE.

And yet, since black diasporic popular music originated along routes established by colonialism and the enslavement of Africans (Gilroy 1993), transnational understandings of hip-hop/R\&B are inseparable from the racial politics of its place(s) of origin. Moreover, black feminist positions on the race-gender intersections of female hip-hop/R\&B celebrity sometimes echo the pop-folk debates. This happens when arguments criticizing commercial hip-hop's "pornographic gaze" towards women of colour (Hunter and Soto 2009; see hooks 1992) contrast with a "hip-hop feminism" tradition (Durham, Cooper and Morris 2013), which locates the agency and entrepreneurship of stars' embodied performance within racialized economies of entertainment and desire. Daphne Brooks, for instance, both points to how Beyoncé mediated intimacy, capital, gender and race to adopt a "female entrepreneur" role" in the mid-2000s (Brooks 2008: 197), and problematizes the "interracial aesthetic encounters" of white female vocalists winning acclaim by "drawing from yet effacing" the sound of black women like Diana Ross (Brooks 2010: 41, 51). Nicole Fleetwood (2012; 2015), likewise, traces the politics of African-American women's hypervisibility through how stars like Ross, or more recently Rihanna, negotiate and subvert racialized/gendered tropes about black women. Latina stars' ambiguously-racialized positions, and the tropes of eroticized “tropicalization” they encounter (Molina Guzmán and Valdivia 2004: 211), meanwhile show a more complex "architecture" of racism behind the "black white binary" that many Americans (and foreigners) perceive (Perry 2005: 141). When R\&B aesthetics circulate globally, such "interracial aesthetic encounters" become transnational.

Contemporary R\&B's race/gender/celebrity configurations thus present both potential analogies with pop-folk and undertheorized connections. Pop-folk is tied to urban peripheries where marginalized residents aspire to (or fantasize about) enrichment in the informal 
economy, is criticized for sexualizing women, and is sometimes visibly - more often invisibly - rooted in the marginal experiences of urban Roma. R\&B represents marginalized groups' intimate lives and musical traditions, represents women in ways some feminists call pornographic, and similarly visualizes characteristic urban spaces through music video and star photography. Indeed, SEE hip-hop and pop-folk producers can use these parallels to identify postsocialist marginality with African-Americans'. However, "race" does not stop at the borders of countries most implicated in colonialism and slavery (Mills 1997).

Postsocialist media studies, therefore, should move beyond analogy to connection - asking how racialized imaginations are "translated" onto local systems of hierarchy (Stam and Shohat 2012).

Such an approach would recognize that pop-folk is often reimagining embodiments of female stardom which originate in US racialized politics of musical celebrity. The "hip hop dreamworld" through which media rework "colonial fantasies about Black women" is global, not just national (Durham 2014: 44-5) - and indeed started shaping east European cultural imaginations of blackness and Romani identity in late state socialism (Todorova 2006; Helbig 2014). Postsocialist studies' latent racial exceptionalism has often obscured these connections. Studies of postcolonial whiteness in "smaller" European countries, however, show how historicizing racialized imaginations of gender, sexuality and the body can help feminist media studies fully combine the postsocialist and postcolonial.

The "cultural archive" of colonialism and whiteness in Europe

Postsocialist studies readily investigate Self-Other constructions around symbolic boundaries of ethnicity. Less often, however, do they situate them within global formations of race and foreground majority nations' identifications with whiteness within their longings to be 
recognized as "European" and "modern." Eastern Europe's long history of foreign domination (under Habsburg/Ottoman/Russian imperial rule; under Soviet control; as Europe's postsocialist semi-periphery) meanwhile complicates regarding it within the same Europe enriched by enslavement and colonial exploitation. Postsocialist feminists using postcolonial thought generally identify the region with the colonized, not colonizers (see Slavova 2006; Cerwonka 2008). ${ }^{5}$ East European Communist parties indeed mobilized this historical experience to build anti-colonial solidarities with the "Third World" - yet their dealings with newly-independent African states often betrayed paternalistic beliefs in European superiority, suggesting they were less disaffiliated from coloniality and ideological structures of whiteness than even they might have believed (Todorova 2006; Kilibarda 2010). The region's experiences under foreign domination did not, however, automatically immunize its people against racism, or against identifying with the colonizer's position. Yet interventions that integrate race into postsocialist SEE studies have not reframed their field like the 1990s adoption of Orientalism did.

Black and postcolonial European studies, however, provide useful methodologies for studying race in European countries without large black populations. German studies, for instance, trace ideologies of "race" and whiteness through consumer culture, popular literature and the arts (e.g., Gilman 1982; Zantop 1997; Campt 2004; Wipplinger 2011), going back to when Habsburg-ruled eastern Europe was within the German-speaking cultural sphere. More recently, Gloria Wekker's intervention against Dutch disavowals of complicity

\footnotetext{
${ }^{4}$ Though see Longinović 2011.

${ }^{5}$ Serbian cultural critic Irena Šentevska (2014: 430), for instance, describes turbo-folk's thematics, situations and female characters as symbolizing "the thirdworldization of post-socialist Eastern Europe, its reality of destruction through development."
} 
in racism and colonial violence resonates with eastern European exceptionalisms despite the two regions' different intra-European structural positions. Via black feminism, Wekker shows the fin-de-siècle white Dutch public was heavily invested in European racial thought's ideologies and stereotypes. Through textbooks, visual arts, anthropological exhibitions, magazines and advertising - that is, through media - the Dutch were learning how to think, see and feel as white European subjects, even though most metropolitan inhabitants had not met people of colour (Wekker 2016: 93-8). Racialized imaginations of black women's bodies and sexuality conveyed this "sexualized racism" (Wekker 2016: 19). What Wekker (2016: 19), following Said, calls the "cultural archive" of Dutch racism and whiteness undercuts the colour-blindness with which white Dutch people often view "race".

While Wekker's work addresses specific Dutch politics, ${ }^{6}$ it also suggests feminists using similar methods could reveal racialized and colonial legacies in countries that were not colonial powers. ${ }^{7}$ Irina Novikova (2013), for instance, has investigated Russian, Latvian and Baltic German meanings of Africa and blackness in reactions to "Dahomey Amazon shows" in Moscow and Riga, ${ }^{8}$ while Dace Dzenovska (2013) traces postsocialist Latvian identifications with the Duchy of Courland's building of trading-posts in Ghana and Tobago.

${ }^{6}$ These include Islamophobic instrumentalizations of LGBT rights, and public harassment of antiracists opposing Dutch blackface carnival traditions.

${ }^{7}$ Studies of postcolonial Nordic whiteness provide excellent illustrations, bridging former colonial powers and nations that were subject to them (Loftsdóttir and Jensen (ed.) 2012): Ylva Habel (2005: 136), for instance, finds Swedish audiences shared "a common European fascination with blackness" in their reception of Josephine Baker.

${ }^{8}$ See also studies of Russian, Soviet and East German encounters with Africa (e.g. Matusevich (ed.) 2007; Slobodian (ed.) 2015). 
Indeed, Miglena Todorova (2006: 93) and Adriana Helbig (2014) both show Anglo-American popular music heavily influenced public understandings of race and blackness in (post)socialist Bulgaria and Ukraine. Cultural stereotypes inferred from hip-hop, cinema and sport, they demonstrate, are powerful enough to even affect how white Ukrainians perceive black Africans or confirm Bulgarian stereotypes about Romani inferiority.

Nevertheless, while race is a global structure, details of racialized categorization vary across space and time. All the societies most studied by racism scholars (the USA, UK, France, South Africa and Brazil) racialize social identities into different categories (Goldberg 2009), as well as contesting these systems internally. The process of translation through which Robert Stam and Ella Shohat (2012) explain the global politics of race is especially useful for understanding these variances because they show that influential models of race are mapped on to existing social hierarchies as they travel. The idea that individuals' ascribed biological origins locate them within a hierarchical geography of modernity/primitivism nevertheless unites different racial formations within "global white supremacy" (Mills 1994: 108). Globally-connected histories of SEE, and other areas, must all contend with this worldhistorical legacy. Since ideologies of gender, sexuality and the body are so deeply embedded in racial formations, and media are so important in conveying these racialized cultural imaginations, feminist media studies have a major role to play in integrating "race" into postsocialism. The racialized politics of female celebrity and pop-folk make this explicit.

\footnotetext{
"Ethnic simultaneity," "erotic multiculturalism," and embodied performance in popfolk
}

While critical race theory and migration history have shown that the ways individuals are racialized as they travel the world do not remain stable, pop-folk female celebrity and its 
translations of embodied aesthetics exported from the USA show that star personas can also be objects of "race in translation" (Stam and Shohat 2012). This occurs primarily through the translation of foreign aesthetics of ethnic and racial ambiguity, or "ethnic simultaneity" (Railton and Watson 2011: 110), into SEE. Transnational audiences may ascribe celebrities different racial identities than they claim, perceive them through "local" systems of racialization instead of their "own", or attach more fixed or ambiguous identities than they have "at home." This asymmetric process occurs within a global political economy of celebrity dominated by US-based corporations and stars. Standards of glamour originally negotiated within US racialized politics of representation thus also constitute the evolving image of contemporary "Westernness" or "Americanness" to which "peripheralized" culture and fashion industries respond.

Pop-folk celebrities' embodied performances are, therefore, created and watched in comparison to foreign star performances which, "at home," could represent gendered and racialized spectacles of whiteness, blackness, Latinity, biraciality, and/or ambiguity. Colonial racializations of white women's sexuality as suitable for civilized domesticity, and black women's sexuality as hypersexually animalistic, still structure such performances (hooks 1992: 34). By adopting dress, movement and vocal styles associated with or created by black women, non-black women can temporarily acquire blackness's erotic appeal and still (if they have access to whiteness) be able to revert to performing white femininity at will (hooks 1992: 21). Some female performers can likewise appropriate exotic Orientalist fantasies (Maira 2008), or sensual, tropical "Latin” stereotypes (Molina Guzmán and Valdivia 2004), across boundaries of personal ethnic heritage. White women, then lighter-skinned women, are more able to transgress these boundaries than darker-skinned women who will not be recognised as white (Railton and Watson 2011: 104). 
The aesthetics of contemporary Western female celebrity therefore contain a knowing mode of "erotic multiculturalism" (Mcgee 2012), including tanned/olive skin, black or honey-coloured hair, fashion practices associated with black/Latina women, and (for singers) "urban" musical signifiers. The ability to perform "a generalised, non-white, exotic "other"” (Railton and Watson 2011: 109) is accessible to certain young, able-bodied women from Latina/Middle Eastern backgrounds, women with diasporic heritage in the Balkans, Mediterranean or Caucasus (like Kim Kardashian), and some light-skinned black and biracial women (e.g. Beyoncé/Rihanna). ${ }^{9}$ The tension this "ethnic simultaneity" (Railton and Wilson 2011: 110) creates between the modes of sexuality expected of differently racialized women is unresolvable if viewers cannot unambiguously determine the star's racial identity. This is part of these stars' celebrity, spectacle and desirability (Sastre 2014: 124). It simultaneously symbolizes narratives of a supposedly "post-racial" America, outside as well as inside the USA.

This lightly-orientalized exotic image exemplifies a category sometimes termed “liminal whiteness" (Ciccariello-Maher 2012) or "white, but not quite” (Alcoff 1998: 9). Many south-east Europeans, indeed, discover Westerners ascribe them this conditional position. As style, it differs from "passing" as white in that its goal is to perform the (bounded and contained) exotic. Moreover, its appeal is enhanced by signifiers of blackness as glamour, problematically detached from unambiguously black bodies (McMillan Cottom

\footnotetext{
${ }^{9}$ Male and female singers representing Mediterranean and Caucasus nations at Eurovision often perform this glamour by mediating essentialised Latinity (Baker 2008: 181-2). Most recently, Eleni Foureira (a Greek singer of Albanian descent who has taken a Greek first name and Portuguese spelling of her surname) was widely compared to Beyoncé while representing Cyprus at Eurovision 2018 with "Fuego" (Mira 2018).
} 
2013). ${ }^{10}$ Investigating how pop-folk female celebrity mediates this aesthetic reveals how postsocialist feminist media studies can engage with global politics of race through the concept of "race in translation," since SEE translations of US racial-ambiguity-as-glamour are filtered through the region's own gendered, sexualized and racialized politics of representation around music and Romani identity.

Historically, music has long conveyed exoticism in SEE. "[S]cales and rhythmic patterns $[\ldots]$ associated with the East, Roma, sex, and passion" have readily coded music as "oriental," "Turkish" or "Middle Eastern," similarly to blackness being sexualized through music in the USA (Silverman 2007: 341). In becoming a mass-media product, pop-folk has even undergone its own form of appropriation, with ethnic-majority stars adopting Romani music's "exotic image and [...] oriental rhythm" while Romani access to the industry's highest tiers declines (Silverman 2012: 185). ${ }^{11}$ For ethnic-majority women in pop-folk to look as if she might be Roma has long been advantageous. This context adds a layer of localized exoticism beneath the performances of modernity that post-millennial pop-folk celebrities make by mastering Western standards of style. Romani people's own identifications between their racialized marginalization in SEE and African-Americans' marginality (Semeziane 2012: 104) create a further hinge between the regions' racialized glamour systems. Indeed, performing globalized, ethnically/racially-ambiguous glamour in pop-folk not only plays on localized politics of representation by intimating Roma identity. It

\footnotetext{
${ }^{10}$ One critique of social-media posts by three Kardashian sisters, for instance, is titled " 9 times the Kardashians stole their looks from Black women" (Dionne 2017).

${ }^{11}$ UNESCO-style race-blind discourses of world cultural heritage, however, would argue that cultural fusions have always inspired creativity and that musicians have the right to borrow freely across cultural boundaries.
} 
also offers the fantasy of prosperity and feminine enterprise symbolized when stars like Seka Aleksić appear to "keep up with" the world's Rihannas, Beyoncés, or Kardashians - that is, to perform a national or Balkan keeping-up with Western modernity itself.

Aleksić's representation, indeed, exemplifies how the popular press mediates fashion, glamour and celebrity. Long after Aleksić had been closely following Rihanna's image (which in turn referenced Grace Jones's), Serbian tabloids still linked their personas through headlines like "Copy paste: Seka's imitating Rihanna again" (Telegraf 2014) and "We were waiting for that: Rihanna copies Seka Aleksić!” (Svet 2012). They quickly reported the US blogger Perez Hilton had endorsed them by nicknaming Aleksić "La Serbian (Wannabe) Rihanna" (Hilton 2010a). Hilton (2010b) had previously called Aleksić's pop-folk colleague Jelena Karleuša (whose videos were resembling Lady Gaga’s futuristic-monstrous camp aesthetic) "La Serbian (Wannabe) GaGa" (Hilton 2010a, 2010b). The Rihanna association distinguished Aleksić in pop-folk stardom just as association with Lady Gaga distinguished Karleuša. The convergence between aesthetics of pop-folk celebrity and ethnic simultaneity nevertheless raises a troubling question: would some performances of liminal whiteness (or even liminal blackness) cross the boundary of racial mimicry?

Post-Yugoslav television occasionally presents literal blackface spectacles, notably the celebrity talent-show Tvoje lice zvuci poznato (Your Face Sounds Familiar), first licensed from Spain in Serbia, Croatia and Slovenia in 2013-14: here, relatively well-known singers impersonate local and global stars in cross-gender and/or cross-racial drag. ${ }^{12}$ Extrapolating Wekker's arguments about everyday Dutch racism (including carnival blackface) to SEE explains this racialized spectacle: if colonial ideologies of gender, sexuality and race really meant nothing in SEE, the sight of a white singer like Minea putting on thick dark brown

\footnotetext{
${ }^{12}$ See Baker 2018: 40-2.
} 
make-up and half-baring her chest as MC Hammer (on one Croatian episode in $2015^{13}$ ) would not excite Croatian viewers. Pop-folk celebrity's everyday appropriations of blackness are not so blatant. Yet how, within a Serbian tabloid's digital gallery fixing Aleksić as a star of "numerous style transformations" (Espreso.rs 2011), should feminists interpret one of Aleksić's looks in 2006 when her skin was darkened to a similar shade as Beyoncé's, with tightly-curled mid-brown hair? ${ }^{14}$ The answer might depend on whether "appropriation" is a meaningful concept in, or translatable into, SEE racial formations and postsocialist feminisms - or whether SEE lies outside Western racial categories altogether.

Is south-east Europe outside Western racial categories?

A 2009 video by the Kosovo Albanian pop-folk star Genta Ismajli, "Si panter i zi” ("Like a black panther"), offers its viewers a spectacle where "Albanian" exists on a par with "white," "black," and "Latina" as a racialized femininity of its own. ${ }^{15}$ While Kosovo Albanian national identity has important differences from the Serbian and Croatian identities discussed

13 “Minea kao MC Hammer: Can't touch this," https://www.youtube.com/watch?v=UEUDQ6Q1D0A (November 26, 2015, accessed August 11, 2017).

${ }^{14}$ The image produces an unfortunate retrospective resemblance to Rachel Doležal, the white woman who controversially claimed "transracial" identity after passing for years as African-American (Phoenix 2017). Doležal's surname is Czech, but also exists in the post-Yugoslav region; its most famous bearer is Sanja Doležal, the (unrelated) front-woman of the 1980s Croatian pop band Novi fosili.

${ }^{15}$ Translations from Albanian courtesy of Isabel Ströhle. 
so far, ${ }^{16}$ Albanian and Kosovar music cultures have much in common with the rest of SEE, including similar cultural politics around pop-folk (Sugarman 2007: 296) and similar remediations of $\mathrm{R} \& \mathrm{~B}$ erotic multiculturalism. They thus reflect wider SEE trends enough to merit discussion in the same context.

"Si panter i zi" likens Ismalji's state when overwhelmed by rhythm to the wild and dangerous embodiment of a black panther, a symbol deeply embedded in white colonial fantasies of primeval Africa as well as its later reclamatory significance to AfricanAmericans. Tropes of associating "women of African descent [...] with an animalistic, "wild" sexuality" have historically permeated gendered structures of "race" (Collins 2004: 27), as have associations between blackness and rhythmicality. Both are thus among the signifiers of blackness strategically available to non-black stars. Sampled panther roars, and Ismaili's clawed gestures, emphasize the symbol. The video follows pop/R\&B convention by splicing together performances in different costumes and spaces. Most sequences index a different racial identity, as the song's English-language break reveals ("Now do it like a black girl... like a white girl... like Latinas"), and each sequence's styling and choreography accentuate embodied signifiers of differently-racialized femininities. ${ }^{17}$ The break's fourth line, "now do

${ }^{16}$ Socialist Yugoslavia recognized South Slavs as constituent peoples (“narodi”), but Albanians (and other groups with external kin-states) only as "nationalities" ("narodnosti"), and Kosovo was not its own republic. Milošević's 1989 revocation of Kosovo's autonomy stripped Albanians of civil rights. Albanians are an ethnic majority within Kosovo (which came under UN administration after the 1998-9 Kosovo War and unilaterally declared independence in 2008), but their experiences as an ethnic minority within Yugoslavia were painful.

${ }^{17}$ As a "black girl" her hair is frizzy and she is entering a club; as a "white girl" her hair is in a straight bob and she is wearing a white blouse; the "Latinas" sequence first places her in a flamenco-like red dress, then among a Shakira-like group of hip-swinging dancers. 
it like an Albanian girl," shows Ismajli in a tightly-belted outfit and severe plait among a mixed-gender group of dancers. The men's shirts and sashes lightly reference folk costume, and all raise their hands like Albanian circle-dances. The video's equivalence between Albanian folk tradition and three named racialized identities suggests the "Albanian" identity presented here is neither black, white or Latina, and may be imagined as outside "race" altogether.

The Albanian-speaking part of pop-folk's musical "ecumene" (Buchanan (ed.) 2007) is in fact the biggest launchpad for SEE translations of R\&B aesthetics to have circulated back into Anglophone pop. This is because several young women from post-Yugoslav Albanian diasporas (Rita Ora, Dua Lipa, Bebe Rexha) became Anglo-American musical celebrities in the $2010 \mathrm{~s},{ }^{18}$ and their diasporic lifeworlds still connect them to Kosovar/Albanian musical cultures. Ora, the most commercially successful and (as Jay-Z's protégée) best connected to US R\&B's political economy, is the most often discussed by feminist critiques of celebrity culture. Some black US feminists have criticized Ora - and Kim Kardashian - for appropriating braided and cornrowed hairstyles (as signifiers of black femininity taken up by white women without credit) and for intimating that she is black or biracial when, in contemporary US terms, she is white (Finley 2015). Here, ethno-national identity and ethnicized "liminal whiteness" matters less than the "black[/]white boundary" (see Perry 2005: 141), to the extent one response even called Ora "the British pop import by

\footnotetext{
${ }^{18}$ Ora was born in Priština and her family settled in London in 1991; in 2008 she signed to Jay-Z's label, Roc Nation. She often visits Kosovo, represents it as a honorary ambassador, and filmed a music video ("Shine Ya Light") there in 2012. Lipa was born in London in 1995 a few years after her parents moved there from Kosovo, and spent her adolescence between Kosovo and Britain. Rexha was born in a Macedonian Albanian family in Brooklyn in 1989.
} 
way of Bosnia" not Kosovo (Carlos 2015). The Bosnia/Kosovo distinction matters significantly in SEE, but to that author it did not alter Ora's place in embodied geographies of racialization (or the ethics of her adopting "black" style). ${ }^{19}$

Kosovo-based female stars, too, often display "fascination with black womanhood" (Strong 2017) through their dance, fashion and hair. The Afro-Latina feminist Alicia Strong (2017) writes that this "would bring accusations of cultural appropriation" in the US. Nevertheless, she continues, the fact that Albanians "although they are white Europeans [...] do not have an extensive history of dominating other cultures" - indeed have been "victims" of imperialism - complicates the binary of privilege which US audiences might apply. Moreover, Ora's upbringing in contemporary London's multiculturally syncretic youth culture (Jones 2017; see Vathi 2015: 107) adds an extra node to the complex transnational politics of representation which a globally-connected feminist reading of SEE female celebrity could acknowledge.

Another way of transnationalizing pop-folk celebrity would be to apply the decolonial feminism of Isis Giraldo (2016: 168-9). Giraldo critiques both the Beyoncé/Rihanna/Shakira mode of "triumphant exoticised female pop icon" and the Ukrainian group Femen's topless protests. Both, she argues, enact gendered forms of colonial difference: while Femen predicate "modernity" on exposing, not covering, female bodies, the pop icons reproduce hypersexual tropes projected onto women of colour while simultaneously accommodating beauty standards of whiteness. Pop-folk's very "feminine libidinal entrepreneurship" (Jelača

\footnotetext{
${ }^{19}$ I do not seek to question the article's broader arguments by pointing out this slip. Rather, I suggest its critique and others like it represent a social fact in contemporary transnational popular music that female celebrities operating within global, not regional, frameworks of stardom must negotiate.
} 
2015) might, in its neoliberal postfeminism, reveal coloniality at work. Yet even Giraldo's connection of two separate gendered and racialized identity performances attaches the two strategies to different regions (the Americas versus postsocialist Europe). In fact, pop-folk's politics of embodiment and representation articulate an even more complex translation of globalized tropes of exoticism into postsocialist national media cultures. It is mediated through localized politics of representation which already use racialized stereotyping and fantasies of exoticism to cast ethnic-majority identities as modern in contrast to Roma. Balkan stars play at keeping up with the Kardashians on this foundation.

Pop-folk celebrity's playing with ethnic/racial ambiguity, therefore, is embedded within a broader "flexible 'racing"" (Cerwonka 2008: 823) of east European women in the global economy of desire. Anna Agathangelou (2004: 88) describes another such configuration, the stereotypical east European sex-worker, as similarly "white but not quite:" "white" by appearance, but on the margins of whiteness in global capital. Indeed, the global political economy racializes women from postsocialist Europe "as white in some cases and as something more ethnic in others" (Cerwonka 2008: 823) - they become "something more ethnic" where their suitability for economic exploitation, or their bodily autonomy, is concerned. Pop-folk female celebrity negotiates this globalizing, commodified standard of ethnically/racially ambiguous glamour and its images of 21st-century American modernity. But it remains interwoven with longer-standing SEE exoticizations and eroticizations of Romani entertainers and with post-Ottoman translations of “orientalism.” Postsocialist feminist media studies' understanding of how postsocialism's material realities have affected women contributes one level of this multi-layered "architecture" (Perry 2005: 141) of race. 
Feminist studies of postsocialist SEE celebrity already incorporate localized formations of race by highlighting constructions of ethnic-majority identities against Romani Others, and the resultant politics of representation and exoticism which media project onto female celebrity. It is rarer for postsocialist media studies to also investigate global formations of race in the production of local celebrity as well as representations of foreign stars, ${ }^{20}$ even though musical celebrity and the eroticized, racially-Othered female body have been among the main vectors of the "translocal glamour and attractiveness of African-American culture" (Gilroy 2000: 346) marketed by entertainment industries. Likewise, postsocialist studies in general are still rarely questioning how far the aspirational identifications with "Europe" reflected across postsocialist societies in the 1990s, and still present in some milieus today, were also identifications with whiteness and the notion of European civilizational superiority that legitimized colonialism. Though some scholars have opened these questions, the wider field has been far slower to take up attention to transnational racial politics and global translations of race as it did orientalism. Perhaps such exceptionalism comes about because discussing global raciality might place eastern Europe in complicity with projects of domination, when hegemonic narratives of east European history are about how severely the region has been dominated.

This paper represents one inflection of a broader problem for media studies around the globe, which Ian Condry (2007: 638) expresses while discussing Japan: "as hip-hop [or R\&B] goes global, what happens to the cultural politics of race inherent in American hiphop?" The SEE inflections exist within the specific cultural politics of postsocialism, where media studies widely understand the adoption of US hip-hop/R\&B's musical/embodied

\footnotetext{
${ }^{20}$ See, however, Adriana Helbig's discussion of the Afro-Ukrainian singer Gaitana (Helbig 2014: 92 $3)$.
} 
practices as "cosmopolitan inscriptions" (Tochka 2017: 166). These permit south-east Europeans, structurally marginalized within Europe, to make "claims to membership in a global order" (Tochka 2017: 166) despite economic constraints and, often, visa restrictions. Female pop-folk celebrities, whatever their own ethnic background, provide sensual and entrepreneurial fantasies and embody mastery of the codes of consumer culture. They thus adapt on to their own bodies the aesthetics of a musical and visual culture which, in its US context, itself sought to display economic success gained outside the structures that had excluded its wearers.

This paper does not aim to pronounce on whether SEE celebrities adopting style across racialized boundaries constitutes the kind of "appropriation" for which white US female celebrities are often held to account. It does, however, show that even conceiving that question requires explicit explanations of how foreign and local celebrities are racialized in SEE: how significant are foreign stars' blackness, Latinity, or whiteness in producing meaning around their star personas in SEE, and how relevant are their ascribed racialized identities when foreign celebrity images are translated into local practices of glamour? Feminist research on pop-folk has widely acknowledged that the genre actively reuses visual, musical and kinaesthetic elements from hip-hop/R\&B ever since this started occurring, and has referenced them within critiquing consumer culture, but only occasionally has it opened out towards postsocialist media's translations of "race."

Translations of racialized glamour in contemporary pop-folk celebrity nevertheless matter to feminist understandings of postsocialist women's experiences in two ways. Firstly, they offer women spectators the pleasure of imagining that coming from the Balkans is an advantage not a disadvantage in embodying transnational style (as consumer culture has encouraged them to do). However, because their localized aesthetics depend on the established othering of Roma, they do not reconfigure the racialized sexual politics of 
nationalism. Further ethnographic, focus-group or online research would also be necessary to draw conclusions about how audiences make sense of this dimension of pop-folk celebrity. Secondly, postsocialist media cultures' responses to foreign media and their racial politics also matter because they affect the material experiences of people of colour in postsocialist countries. ${ }^{21}$ Knowing that "many of [one's] interactions in public spaces" will occur "in conversation with these images" (Fleetwood 2015: 1), in ways that involve gender as well as race, is visceral everyday knowledge for people of colour in postsocialist Europe as well as the USA. It is visceral everyday knowledge, too, for European Roma, who also contend with white-majority publics who perceive their identities and lives through stereotyped media representations (Imre 2015).

What postsocialist feminist media studies can learn from these pop-folk examples is that postsocialist media's aesthetics of "American" and "European" glamour are racialized aesthetics - and, often, aesthetics of African-American (and Afro-European) glamour or postracial multiculturalism. Their remediation translates them into societies where nationalist ideologies of modernization, internal ethnicized and sometimes racialized Self-Other dynamics, state socialist race-blind anticolonialism, and the region's past/present peripheralization within Europe have produced ambiguous identifications with and against coloniality and whiteness itself. Combining postsocialist and postcolonial studies, and establishing the "transcultural" feminist dialogues Nadia Kaneva (2015: 12) calls for, requires feminist media critics, and other scholars, to make these connections explicit. This involves confronting not only the marginalizations that have led south-east Europeans to construct shifting identifications with racialized minorities elsewhere, but also the postsocialist and pre-

${ }^{21}$ E.g., Strong (2017) writes that in Kosovo "[m]en would often follow [her] and scream the names of random black female celebrities." 
postsocialist investments in whiteness that help sustain global formations of race. The concept of race in translation gives postsocialist feminist media studies the tools to confront these.

References

Agathangelou, Anna M. 2004. The Global Political Economy of Sex: Desire, Violence and Insecurity in Mediterranean Nation States. London and New York: Routledge.

Alcoff, Linda Martín. 1998. "What Should White People Do?” Hypatia 13 (3): 6-26.

Archer, Rory. 2012. "Assessing Turbofolk Controversies: Popular Music between the Nation and the Balkans." Southeastern Europe 36 (2): 178-207.

Baker, Catherine. 2008. "Wild Dances and Dying Wolves: Simulation, Essentialization, and National Identity at the Eurovision Song Contest." Popular Communication 6 (3): $173-89$.

Baker, Catherine. 2018. Race and the Yugoslav Region. Manchester: Manchester University Press.

Bakić-Hayden, Milica. 1995. "Nesting Orientalisms: the Case of Former Yugoslavia.” Slavic Review 54 (4): 917-31.

Beissinger, Margaret. 2001. "Occupation and Ethnicity: Constructing Identity Among Professional Romani (Gypsy) Musicians.” Slavic Review 60 (1): 24-49.

Bilge, Sirma. 2013. "Intersectionality Undone: Saving Intersectionality from Feminist Intersectionality Studies.” Du Bois Review 10 (2): 405-24.

Bilić, Bojan, and Sanja Kajinić. 2016. "LGBT Activist Politics and Intersectionality in Croatia and Serbia: an Introduction." In Intersectionality and LGBT Activist Politics: Multiple Others in Croatia and Serbia, edited by Bojan Bilić and Sanja Kajinić, 1-30. London: Palgrave Macmillan.

Bjelić, Dušan I. 2009. “Immigrants as the Enemy: Psychoanalysis and the Balkans' SelfOrientalization." Slavonic and East European Review 87 (3): 488-517.

Bjelić, Dušan I. 2017. "Bulgaria's Zionism, the Colonization of Palestine and the Question of Balkan Postcoloniality." Interventions 19 (2): 218-37. 
Blagojević, Marina. 2009. Knowledge Production at the Semiperiphery: a Gender

Perspective. Belgrade: Institut za kriminološka i sociološka istraživanja.

Brooks, Daphne A. 2008. ““'All That You Can't Leave Behind”: Black Female Soul Singing and the Politics of Surrogation in the Age of Catastrophe." Meridians 8 (1): 180-204.

Brooks, Daphne A. 2010. “This Voice Which is Not One”: Amy Winehouse Sings the Ballad of Sonic Blue(s)face Culture." Women and Performance 20 (1): 37-60.

Buchanan, Donna A. 1997. "Bulgaria's Magical Mystère Tour: Postmodernism, World Music Marketing, and Political Change in Eastern Europe.” Ethnomusicology 41 (1): 13157.

Buchanan, Donna A. 2006. Performing Democracy: Bulgarian Music and Musicians in Transition. Chicago, IL: University of Chicago Press.

Buchanan, Donna A. 2007. "Bulgarian Ethnopop along the Old Via militaris: Ottomanism, Orientalism, or Balkan Cosmopolitanism?" In Balkan Popular Culture and the Ottoman Ecumene: Music, Image, and Regional Political Discourse, edited by Donna A. Buchanan, 225-67. Lanham, MD: Scarecrow Press.

Buchanan, Donna A. (ed.) 2007. Balkan Popular Culture and the Ottoman Ecumene: Music, Image, and Regional Political Discourse. Lanham, MD: Scarecrow Press.

Campt, Tina M. 2004. Other Germans: Black Germans and the Politics of Race, Gender, and Memory in the Third Reich. Ann Arbor, MI: University of Michigan Press.

Carlos, Marjon. 2015. "Rita Ora’s Not Black, But Her Hair Sure Thinks She Is.” Splinter.

May 26, 2015. Accessed August 11, 2017. http://splinternews.com/rita-ora-s-notblack-but-her-hair-sure-thinks-she-is-1793847958

Cerwonka, Allaine. 2008. “Traveling Feminist Thought: Difference and Transculturation in Central and Eastern European Feminism.” Signs 33 (4): 809-32.

Chari, Sharad, and Katherine Verdery. 2009. "Thinking Between the Posts: Postcolonialism, Postsocialism, and Ethnography after the Cold War." Comparative Studies in Sociology and History 51 (1): 6-34.

Ciccariello-Maher, George. 2012. “The Dialectics of Standing One's Ground.” Theory and Event 15 (3). Accessed August 11, 2017. https://muse.jhu.edu/article/484431

Collins, Patricia Hill. 2004. Black Sexual Politics: African Americans, Gender, and the New Racism. London and New York: Routledge.

Čolović, Ivan. 2006. Etno: priče o muzici sveta na Internetu. Belgrade: XX vek.

Condry, Ian. 2007. "Yellow B-Boys, Black Culture, and Hip-Hop in Japan: Toward a Transnational Cultural Politics of Race.” Positions 15 (3): 637-71. 
Dimitrijević, Olga. 2008. "The Body of the Female Folk Singer: Constructions of National Identities in Serbia after 2000." MA dissertation, Central European University.

Dionne, Evette. 2017. "9 Times the Kardashians Stole Their Looks from Black Women."

Revelist. February 14. Accessed August 11, 2017.

http://www.revelist.com/race/kardashians-cultural-appropriation/6850

Dragićević-Šešić, Milena. 1994. Neofolk kultura: publika i njene zvezde. Novi Sad:

Izdavačka knjižarnica Zorana Stojanovića.

Dumančić, Marko, and Krešimir Krolo. 2017. "Dehexing Postwar West Balkan

Masculinities: The Case of Bosnia, Croatia, and Serbia, 1998 to 2015." Men and Masculinities 20 (2): 154-80.

Durham, Aisha. 2012. “'Check On It:’ Beyoncé, Southern Booty, and Black Femininities in Music Video.” Feminist Media Studies 12 (1): 35-49.

Durham, Aisha, Brittney C. Cooper and Susana M. Morris. 2013. "The Stage Hip-Hop Feminism Built: a New Directions Essay.” Signs 38 (3): 721-37.

Dzenovska, Dace. 2013. "Historical Agency and the Coloniality of Power in Postsocialist Europe." Anthropological Theory 13(4): 394-416.

Dzodan, Flavia. 2016. "My Feminism Will Be Capitalist, Appropriative, and Bullshit Merchandise.” Athena Talks (blog). August 9, 2016. Accessed August 10, 2017. https://medium.com/athena-talks/my-feminism-will-be-capitalist-appropriative-andbullshit-merchandise-d1064490d8fb

Espreso.rs. 2011. "Seka Aleksić: spremna za promene.” Glossy (blog). February 14, 2011.

Accessed August 11, 2017. http://glossy.espreso.rs/galerije/albumizvezda/13664/seka-aleksic-spremna-za-promene/media/3350/6

Finley, Taryn. 2015. "8 Times Black Hairstyles Have Been Culturally Appropriated." Huffington Post, July 17. Accessed July 15, 2017. http://www.huffingtonpost.com/entry/9-times-white-people-have-appropriated-blackhairstyles-since-2014_us_55a81211e4b0896514d0c3ca

Fleetwood, Nicole R. 2012. "The Case of Rihanna: Erotic Violence and Black Female Desire." African American Review 45 (3): 419-35.

Fleetwood, Nicole R. 2015. On Racial Icons: Blackness and the Public Imagination. Princeton, NJ: Rutgers University Press.

Gilman, Sander L. 1982. On Blackness Without Blacks: Essays on the Image of the Black in Germany. Boston, MA: G.K. Hall. 
Gilroy, Paul. 1993. The Black Atlantic: Modernity and Double Consciousness. London: Verso.

Gilroy, Paul. 2000. Between Camps: Nations, Cultures and the Allure of Race. London: Penguin.

Giraldo, Isis. 2016. "Coloniality at Work: Decolonial Critique and the Postfeminist Regime." Feminist Theory 17 (2): 157-73.

Goldberg, David Theo. 2009. The Threat of Race: Reflections on Racial Neoliberalism. Oxford: Blackwell.

Gordy, Eric D. 1999. The Culture of Power in Serbia: Nationalism and the Destruction of Alternatives. University Park, PA: Pennsylvania State University Press.

Gotthardi Pavlovsky, Aleksej. 2014. Narodnjaci i turbofolk u Hrvatskoj: zašto ih (ne) volimo? Zagreb: Ljevak.

Grujić, Marija. 2009. "Community and the Popular: Women, Nation and Turbo Folk in PostYugoslav Serbia.” PhD dissertation, Central European University.

Habel, Ylva. 2005. “To Stockholm, with Love: The Critical Reception of Josephine Baker, 1927-35." Film History 17 (1): 125-38.

Haliliuc, Alina. 2015. "Manele Music and the Discourse of Balkanism in Romania." Communication, Culture and Critique 8 (2): 290-308.

Helbig, Adriana N. 2014. Hip-Hop Ukraine: Music, Race, and African Migration. Bloomington, IN: Indiana University Press.

Herzfeld, Michael. 2005. Cultural Intimacy: Social Poetics in the Nation-State. 2nd ed. London and New York: Routledge.

Hilton, Perez. 2010a. "From the People Who Brought You La Serbian (Wannabe) GaGa..." Perez Hilton (blog). March 6, 2010. Accessed August 14, 2017. http://perezhilton.com/2010-03-06-from-the-people-who-brought-you-la-serbianwannabe-gaga\#.V1b88WOhaJ0

Hilton, Perez. 2010b. “La Serbian (Wannabe) GaGa!” Perez Hilton (blog). March 3, 2010. Accessed August 14, 2017. http://perezhilton.com/2010-03-03-la-serbian-wannabegaga\#.V1b9LWOhaJ0

hooks, bell. 1992. Black Looks: Race and Representation. Boston, MA: South End Press.

Hunter, Margaret, and Kathleen Soto. 2009. "Women of Color in Hip Hop: the Pornographic Gaze." Race, Gender and Class 16 (1-2): 170-91.

Ibroscheva, Elza. 2013. "Selling the Post-Communist Female Body: Portrayals of Women and Gender in Bulgarian Advertising." Feminist Media Studies 13 (3): 443-62. 
Imre, Anikó. 2005. "Whiteness in Post-Socialist Eastern Europe: the Time of the Gypsies, the End of Race." In Postcolonial Whiteness: a Critical Reader on Race and Empire, edited by Alfred J López, 79-102. Albany, NY: SUNY Press.

Imre, Anikó. 2014. "Postcolonial Media Studies in Postsocialist Europe.” Boundary 241 (1): $113-34$.

Imre, Anikó. 2015. "Love to Hate: National Celebrity and Racial Intimacy on Reality TV in the New Europe." Television and New Media 16 (2): 103-30.

Iordanova, Dina. 2001. Cinema of Flames: Balkan Film, Culture and the Media. London: BFI.

Jelača, Dijana. 2015. "Feminine Libidinal Entrepreneurship: Towards a Reparative Reading of the Sponzoruša in Turbo Folk." Feminist Media Studies 15 (1): 36-52.

Jones, Bronwyn. 2017. "Being a Black Woman in Kosovo.” Prishtina Insight. July 24, 2017. Accessed August 11, 2017. http://prishtinainsight.com/black-woman-kosovo/

Kaneva, Nadia. 2015. "Mediating Post-Socialist Femininities.” Feminist Media Studies 15 (1): $1-17$.

Kilibarda, Konstantin. 2010. "Non-Aligned Geographies in the Balkans: Space, Race and Image in the Construction of New 'European' Foreign Policies.” In Security Beyond the Discipline: Emerging Dialogues on Global Politics, edited by Abhinava Kumar and Derek Maisonville, 27-57. Toronto: York Centre for International and Security Studies.

Kronja, Ivana. 2004. "Turbo Folk and Dance Music in 1990s Serbia: Media, Ideology and the Production of Spectacle.” Anthropology of East Europe Review 22 (1): 103-14.

Loftsdóttir, Kristín, and Lars Jensen (ed.). 2012. Whiteness and Postcolonialism in the Nordic Region: Exceptionalism, Migrant Others and National Identities. Farnham: Ashgate.

Longinović, Tomislav Z. 2011. Vampire Nation: Violence as Cultural Imaginary. Durham, NC: Duke University Press.

Maira, Sunaina. 2008. "Belly Dancing: Arab-Face, Orientalist Feminism, and U.S. Empire." American Quarterly 60 (2): 317-45.

Marković, Aleksandar. 2015. “'So That We Look More Gypsy’: Strategic Performances and Ambivalent Discourses of Romani Brass for the World Music Scene." Ethnomusicology Forum 24 (2): 260-85.

McGarry, Aidan. 2017. Romaphobia: the Last Acceptable Form of Racism. London: Zed. 
Mcgee, Kristin. 2012. "Orientalism and Erotic Multiculturalism in Popular Culture: from Princess Rajah to the Pussycat Dolls." Music, Sound, and the Moving Image 6 (2): 209-38.

McMillan Cottom, Tressie. 2013. "When Your (Brown) Body is a (White) Wonderland." Some Of Us Are Brave (blog), August 27, 2013. Accessed August 11, 2017. https://tressiemc.com/uncategorized/when-your-brown-body-is-a-white-wonderland/

Mills, Charles W. 1994. "Revisionist Ontologies: Theorizing White Supremacy.” Social and Economic Studies 43 (3): 105-34.

Mira, Nieves. 2018. "Eleni Foureira: la Beyoncé mediterránea que busca conquistar Eurovisión.” ABC Play, May 12, 2018. Accessed July 10, 2018.

https://www.abc.es/play/television/eurovision/abci-eleni-foureira-cancion-chipreeurovision-2018-fuego-201805121101_noticia.html

Molina Guzmán, Isabel, and Angharad N. Valdivia. 2004. "Brain, Brow, and Booty: Latina Iconicity in U.S. Popular Culture.” The Communication Review 7 (2): 205-21. Novikova, Irina. 2013. "Imagining Africa and Blackness in the Russian Empire: from ExtraTextual Arapka and Distant Cannibals to Dahomey Amazon Shows - Live in Moscow and Riga." Social Identities 19 (5): 571-91.

Papić, Žarana. 2002. "Europe after 1989: Ethnic Wars, the Fascisation of Social Life and Body Politics in Serbia." Filozofski vestnik 23 (2): 191-205.

Perry, Imani. 2005. "Of Desi, J. Lo and Color Matters: Law, Critical Race Theory and the Architecture of Race." Cleveland State Law Review 52: 139-53.

Pettan, Svanibor. 2001. “Encounter with ‘the Others from Within': the Case of Gypsy Musicians in Former Yugoslavia." World of Music 43 (2-3): 119-37.

Phoenix, Ann. 2017. "Unsettling Intersectional Identities: Historicizing Embodied Boundaries and Border Crossings.” Ethnic and Racial Studies 40 (8): 1312-19. Railton, Diane, and Paul Watson. 2011. Music Video and the Politics of Representation. Edinburgh: Edinburgh University Press.

Rasmussen, Ljerka V. 2002. Newly-Composed Folk Music of Yugoslavia. London and New York: Routledge.

Rucker-Chang, Sunnie. Forthcoming. "Roma Filmic Representation as Postcolonial 'Object.'” Interventions.

Samson, Jim. 2013. Music in the Balkans. Leiden: Brill.

Sastre, Alexandra. 2014. "Hottentot in the Age of Reality TV: Sexuality, Race, and Kim Kardashian's Visible Body." Celebrity Studies 5 (1-2): 123-37. 
Semeziane, Sarah. 2012. "Roma Rap and the Black Train: Minority Voices in Hungarian Hip Hop.” In The Languages of Global Hip Hop, edited by Marina Terkourafi, 96-119. London: Continuum.

Šentevska, Irena. 2014. "Turbo-Folk as the Agent of Empire: on Discourses of Identity and Difference in Popular Culture." Journal of Narrative Theory 44 (3): 413-41.

Shome, Raka. 2006. "Transnational Feminism and Communication Studies." The Communication Review 9 (4): 255-67.

Silverman, Carol. 2007. "Trafficking in the Exotic with "Gypsy" Music: Balkan Roma, Cosmopolitanism, and "World Music" Festivals." In Balkan Popular Culture and the Ottoman Ecumene: Music, Image, and Regional Political Discourse, edited by Donna A. Buchanan, 335-61. Lanham, MD: Scarecrow Press.

Silverman, Carol. 2012. Romani Routes: Cultural Politics and Balkan Music in Diaspora. Oxford: Oxford University Press.

Slavova, Kornelia. 2006. "Looking at Western Feminisms Through the Double Lens of Eastern Europe and the Third World." In Women and Citizenship in Central and Eastern Europe, edited by Jasmina Lukić, Joanna Regulska and Darja Zaviršek, 24563. Aldershot: Ashgate.

Slobodian, Quinn (ed.). 2015. Comrades of Color: East Germany in the Cold War World. Oxford: Berghahn.

Stam, Robert, and Ella Shohat. 2012. Race in Translation: Culture Wars around the Postcolonial Atlantic. New York: New York University Press.

Stokes, Martin. 1992. The Arabesk Debate: Music and Musicians in Modern Turkey. Oxford: Clarendon Press.

Strong, Alicia. 2017. "Race and Racism in Kosovo: an Afro-Latina American Woman's Perspective.” Prishtina Insight. July 21, 2017. Accessed August 11, 2017. http://prishtinainsight.com/race-racism-kosovo/

Svet. 2012. "I to smo dočekali: Rijana iskopirala Seku Aleksić!” Svet. October 16, 2012.

Accessed August 14, 2017. http://www.svet.rs/nas-svet/estrada/i-to-smo-docekalirijana-iskopirala-seku-aleksic

Szeman, Ioana. 2013. “'Playing with Fire' and Playing it Safe: With(out) Roma at the Eurovision Song Contest?” In Performing the New Europe: Identities, Feelings and Performances in the Eurovision Song Contest, edited by Karen Fricker and Milija Gluhović: 125-41. Basingstoke: Palgrave Macmillan. 
Telegraf. 2014. “Kopi/pejst: Seka opet imitira Rijanu!” Telegraf. September 8, 2014.

Accessed August 14, 2017. http://www.telegraf.rs/jetset/1217283-kopi-pejst-sekaopet-imitira-rijanu-foto

Tochka, Nicholas. 2017. “Cosmopolitan Inscriptions?: Mimicry, Rap, and Rurbanity in PostSocialist Albania." In Hip Hop at Europe's Edge: Music, Agency, and Social Change, edited by Milos Miszczynski and Adriana Helbig, 165-81. Bloomington, IN: Indiana University Press.

Todorova, Maria. 2009. Imagining the Balkans. 2nd ed. Oxford: Oxford University Press.

Todorova, Miglena S. 2006. "Race Travels: Whiteness and Modernity Across National Borders." PhD thesis, University of Minnesota.

Van de Port, Mattijs. 1998. Gypsies, Wars and Other Instances of the Wild: Civilization and its Discontents in a Serbian Town. Amsterdam: Amsterdam University Press.

Vathi, Zana. 2015. Migrating and Settling in a Mobile World: Albanian Migrants and Their Children in Europe. Cham: SpringerOpen.

Verdery, Katherine. 1994. "From Parent-State to Family Patriarchs: Gender and Nation in Contemporary Eastern Europe.” East European Politics and Societies 8 (2): 225-55.

Volčič, Zala. 2013. "Connecting the Disconnected: Balkan Culture Studies.” Communication and Critical/Cultural Studies 10 (2-3): 333-9.

Volčič, Zala, and Karmen Erjavec. 2010. "The Paradox of Ceca and the Turbo-Folk Audience." Popular Communication 8 (2): 103-19.

Wekker, Gloria. 2016. White Innocence: Paradoxes of Colonialism and Race. Durham, NC: Duke University Press.

Wipplinger, Jonathan. 2011. "The Racial Ruse: on Blackness and Blackface Comedy in Finde-Siècle Germany." German Quarterly 84 (4): 457-76.

Zantop, Suzanne. 1997. Colonial Fantasies: Conquest, Family, and Nation in Precolonial Germany, 1770-1870. Durham, NC: Duke University Press.

Žarkov, Dubravka. 2007. The Body of War: Media, Ethnicity, and Gender in the Break-Up of Yugoslavia. Durham, NC: Duke University Press. 
Catherine Baker is Senior Lecturer in 20th Century History at the University of Hull, and specializes in the transnational politics of post-Cold-War media. Her publications include Sounds of the Borderland: Popular Music, War and Nationalism in Croatia since 1991 (2010), The Yugoslav Wars of the 1990s (2015) and Race and the Yugoslav Region: Postsocialist, Post-Conflict, Postcolonial? (2018), plus articles in International Feminist Journal of Politics, Slavic Review, European Journal of International Relations and elsewhere. 